\title{
Managing labour: UK and Australian employers in comparative perspective, 1900-50
}

The exceptionalism of Australian industrial relations has long been asserted. In particular, the Australian system of industrial arbitration has been argued to contrast markedly with other countries, such as Britain, which developed a more 'voluntarist' model of industrial regulation. However this distinction relies upon limited historical research of workplace-level developments. In this paper, we focus on a comparative analysis of employer practice in British and Australian workplaces during the first half of the twentieth century. While we find some differences in the nature and extent of management control between the British and Australian experience, what is more striking are the strong similarities in employer practice in work organisation, employment and industrial relations. While economic and institutional factors explain differences in employer practice, fundamental similarities appear to relate to the close economic and social linkages between British and Australian business.

Since the 1980s, researchers have broadened the ambit of labour history and focussed on a widening range of issues including the changing nature of work, the labour process and the role of employer practice in shaping employees' working lives. Not only has such a research agenda enriched the study of labour history, but it has also led to a reassessment of traditional conceptions of the history of working life. Most critically, the role of management appears intimately linked with the activities of workers and trade unions; the interaction of these parties resulting in a rich and varied history of workplace relations across time and space. While historical studies of employers within particular country settings have increased, international comparative analysis of employer practice has been less common. Such comparative analysis is important in developing theoretical conceptions of employer practice beyond the context of specific national economic settings. Two studies which stand out in this respect are Littler's The Development of the Labour Process in Capitalist Societies and Tolliday and Zeitlin's edited volume The Power to Manage? A key finding from these studies is that rather than a single means of capitalist control, labour management has varied significantly between countries. This has related both to the types of strategies employed, as well as the timing and extent of specific employment practices. These studies have also provided a more complex interpretation of factors which have shaped such variation. While divergent economic contexts are clearly central in shaping employer strategies and behaviour, so too are differing institutional environments.

In this article we seek to expand the historical comparison of employers to an analysis of labour management practice in Britain and Australia. Comparisons of the industrial relations systems in these two countries have traditionally highlighted fundamental differences, particularly what can be termed Australian 'exceptionalism' in the adoption of a system of compulsory state industrial arbitration at the beginning of the twentieth century. This has been argued to contrast with a British industrial relations system based on 'voluntarism' and a lack of state involvement.For instance, historical 
studies of Australian trade unions and industrial relations have often asserted that industrial arbitration resulted in a distinctive pattern of behaviour (dependent unions, weak employers and centralised wage determination), which differed significantly from the British and American examples.Beyond differences in industrial regulation we can also note variations in the size and scale of the British and Australian economies, population size, and geography. On the one hand then, our study appears to contrast employer practice in two very different national contexts (what is often termed a 'most different' comparative approach). However, there are also aspects about the history of these two countries which hint at fundamental similarities. Most importantly, Australia as a nation originated as a collection of British colonies and even after nationhood, remained a steadfast dominion within the British Empire. Moreover, the vast bulk of the Australian population were British migrants, and Australia inherited a British legal and political system. Indeed it was not until the 1970s that some of the vestiges of Australia's British heritage were challenged, symbolised in debates over the national anthem, flag, and more recently, the British monarch as head of state. In terms of economic development, as Cochrane has argued, Australian industry was closely modelled on the needs of the British economy and existed up until the second half of the twentieth century in a dependent relationship with the 'mother country'. These strong economic and social ties highlight the potential for similarities in employer practice, as Australian employers modelled themselves on the example of the 'parent' British economy. In this article, we compare employer practice in British and Australian industry during the first half of the twentieth century. How did employer practice vary between the two countries, and to what extent did the so-called 'exceptionalism' of Australian industrial arbitration result in a distinctive pattern of workplace labour management? In order to structure our analysis of employer practice in the two countries, we have adopted Gospel's conceptual framework of labour management which distinguishes between work relations, that is how management chooses to organise the technical and social features of work; employment relations, encompassing the arrangements governing recruitment, selection, training, and reward of employees; and industrial relations, which refers to the way in which employers manage organised labour and deal with collective labour pressures such as trade unions and the nature of bargaining. In our comparison of British and Australian employer practice from 1900-50, a key difference we argue relates to the slower adoption of more sophisticated labour management strategies in Australian industry, reflecting the less developed and smaller scale nature of manufacturing industry, as well as Australian employers' geographic isolation from the heartland of industrialisation in the Northern Hemisphere. However, beyond differences, what is more interesting are the marked similarities between British and Australian management practice in the period up to World War II. We suggest that while economic, structural and institutional factors are important in explaining differences in employer practice between the two countries, the similarities relate to the close economic and social linkages between Britain and Australia.

\section{Comparative Patterns of Industrialisation and Work Organisation}

British and Australian enterprises underwent significant change during the early twentieth century in terms of the scale and scope of their operations as well as their 
internal organisation. In general, these changes were earlier and more significant in the British case, with the period from c1890-1914 marking a dramatic increase in the scale of industrial enterprises, as family firms gave way to the modern business corporation. This brought the modern works manager and, in the larger plants, a more sophisticated managerial hierarchy of functional departments and supervisors. Singer in Clydebank, Westinghouse and Ford in Manchester were examples. However, there were limits to this process, as family dynasties often managed to retain control on the new boards of directors and the emergence of a group of professional managers was slower in Britain than either the USA or Germany. There was a tendency for British employers to eschew new methods, to favour ad hoc managerial techniques and labour-intensive production methods over capital-intensive ones. Australian industry underwent similar changes although these lagged in comparison to Britain. As part of the British Empire, Australia's economic development was closely tied to the needs of the 'mother country', first as a source of primary produce and later as a location for British investment. As Cochrane has highlighted, Australian economic development was fundamentally linked to its dependent relationship upon British capital and technical expertise. As a result, the British model of management had a powerful impact upon Australia's early industrialists. As the Times Trade Supplement argued in 1919:

It is highly necessary that British industry should make certain of being and remaining the first and strongest influence upon the young industrial communities overseas. The education of the coming overseas captains of industry - upon British lines — can effect much.

The development of Australian manufacturing industry accelerated during the early 1900s following the federation of the colonies, the introduction of unified tariff protection, and increased processing of primary exports. In the first decade of the 1900s, investment in secondary industry more than doubled, and by 1914 the value of factory production rivalled the rural sector. These trends were reinforced during World War I. Population growth, immigration, and strengthened tariff protection after the war assisted the expansion of a viable industrial base with the formation of large industrial enterprises in the steel, glass, paper, and chemical industries. The nature of production also underwent fundamental change as foreign firms set-up manufacturing operations behind the tariff wall. While many of these larger industrial concerns were based on British investment and the importation of British technical and managerial expertise, there were exceptions such as the Broken Hill Proprietary (BHP) Company's establishment of steel production and the entry of overseas car manufacturers, both of which introduced American production techniques of mass production. Despite these advances, Australia's small domestic market limited economies of scale, resulting in a large number of small-scale producers. As was the case in Britain, despite the moves towards large integrated enterprises, family owned and managed firms remained as dominant features of the industrial landscape. At the shopfloor level, the organisation of work in both economies varied by ownership structure, size and industry. Despite the attention directed in academic scholarship to formalised techniques of shopfloor control such as scientific management and mass production, what is noticeable in both the British and Australian contexts is the dominance of 'simple control' in most manufacturing establishments. This was pronounced in small firms, where control of the workforce was the concern of the owner-manager or working proprietor. These employers exercised a wide discretion over the firm's affairs, including the supervision and direction of production, the hiring and firing of workers, and the allocation of bonuses and other positive inducements. In larger firms, 'simple control' was often delegated. In the British case, 
the nineteenth century model of internal sub-contracting which was common in industries such as mining (butty system), ironworking, dockwork, navvying, shipbuilding, pottery, clothing and textiles, provided one alternative model. However, by the late nineteenth century, the engagement of sub-contractors was in decline, as employers sought to improve productivity and increase their direct control over the shopfloor. In their place, simple control fell to the foreman. In both the British and Australian contexts, the foreman was often central to the successful management of the manufacturing enterprise. The foreman's discretion commonly extended to questions of production, cost and quality control, having worked for many years as a skilled tradesman, and having an intimate knowledge of the production process. Here the foreman's control was often tempered by the craft skill of the workforce. For instance, in boot-making, printing, coal-mining and shearing, workers often exercised a high degree of autonomy over working hours and methods, favouring piecework payment and commonly instituting collective output quotas and other forms of work regulation.

In the newer mass production industries such as automobile, electrical appliance, and steel manufacture, the foreman's role as shopfloor manager was critical to the management of the firm. Jacoby's conception of the 'driving' method of supervision in American industry, appears directly relevant here. Examples of large British and Australian firms highlight the role of the foreman maximising output through a combination of bullying, compulsion and authoritarian rule. Foremen maintained close surveillance over worker behaviour and instituted strict discipline aimed at minimising time-wasting and 'unproductive' behaviour. Under such a system, it was not uncommon for foremen to abuse workers or apply arbitrary penalties in an effort to increase production. Alfred Williams noted such tendencies with disgust in his evocative portrayal of work before World War I in the Great Western Railway Works in Swindon. Tighter supervision facilitated the intensification of work pace. So too did the spread of piecework and bonus wage payment systems. These developments took place in tandem with job fragmentation and work reorganisation which in itself had a labour control function; a deskilled workforce was not only cheaper to employ, but more flexible, more easily replaced, more directly managed and less autonomous. This trend was evident in British and Australian industry during the early decades of the twentieth century. Most pronounced were the developments towards mass production in industries such as steel, automobile, electrical appliance, rubber and armaments manufacture. In Australia, employers in these industries introduced foreign models of quantity production and systematic management. For instance, during the mid-1920s, North American manufacturers such as Ford and General Motors, established Australian assembly plants which employed the most up to date thinking on shop layout, routing, the use of specialised machinery, and new methods of production flow and material handling (most notably the moving assembly line). Following the American lead, local vehicle manufacturers such as Holden's also introduced quantity production techniques. A similar pattern occurred in the fledgling electrical appliance industry, for example in Metropolitan Vickers and Philips.

British and Australian employers also introduced more formalised techniques of labour control such as scientific management during this period, although the extent of 'Taylorism' has been subject to significant debate. In his writings and consultancy work in the United States in the 1890s and 1900s, Frederick Taylor challenged employers to exercise their authority in the workplace; to reach down and wrest 
control and power from workers. His system, enshrined in The Principles of Scientific Management published in 1911 necessitated 'a complete revolution in the mental attitude and the habits of all those engaged in management'. The main objective of Taylor and later work study specialists was to replace the ad hoc, unsystematic managerial 'rule of thumb' with scientific methods of control which would maximise productivity. The techniques of the efficiency engineers included detailed analysis of the way that work was performed, with operations timed with a stop watch and work motions closely analysed.

There were distinct moves in the direction of scientific management within Britain before World War I, with a whole genre of management literature and practical experiments in work rationalisation and premium bonus wage systems. Whitston has argued that before 1914 'the British reception of Taylorism was more positive than has been supposed' and how the 'fracturing of conception and execution ... was developing independently in British engineering workshops from the turn of the century'. Nonetheless, the evidence suggests that the initial response to Taylorist ideas in Britain was a relatively lukewarm one: British employers were more sceptical and less receptive than their counterparts in the USA, Germany, Italy and France before 1914. This was linked to poor management education in Britain and entrepreneurial conservatism, as well as the fear of labour opposition in a period of tight labour markets, growing trade union membership and escalating labour militancy between 1910-14. While there were some direct experiments with Taylorist methods, such as at Cadbury, Renold's, Weir's, and Rowan and Singer, these were rare occurrences.

During the 1920s to 1940s Taylorist ideas diffused more widely throughout British industry. The inter-war depression and the two world wars acted as incubators of new production management ideas, promoting time and motion study, flow production methods, deskilling and new managerial structures and methods. A key source of Taylorist diffusion during the inter-war years was the American management consultant Charles E. Bedaux, whose company worked for over 220 British manufacturing firms and implemented the Bedaux system of time study and wage incentives. Nonetheless, the extent and the pace of change should not be exaggerated. Urwick and Brech noted in their survey of the scientific management movement, that knowledge of Taylorism was still poor in 1939 and estimated that only around one in ten British companies had actually introduced elements of scientific management. Most employers between the wars resorted to traditional methods of intensifying work with a range of labour relations strategies, including external delegation and institutionalised welfarism. Opposition from both workers and foremen and a clutch of strikes also retarded the progress of the Bedaux system and modified its impact in the 1930s. World War II provided a further boost to the efficiency engineers and the 1940s witnessed further bureaucratisation of work, with more sophisticated management structures and a commensurate erosion in workers' independence and discretion at the point of production. Workers' opposition was also more muted (the Trade Union Congress officially supported Taylorism from 1933), whilst the popularity of American productionist ideas increased, in contrast to the inter-war period, when such ideas were associated with the loss of employment and degradation of skills. However, management restructuring along Taylorist lines was extremely uneven. Scientific management was often limited in practice to the largest manufacturing companies, particularly in the newer, mass production industries, with prominent examples including the main car companies (Ford; Austin; Morris), ICI, Wolsey, Lucas, Westinghouse, Ferranti, Hoover, Morphy-Richards, Cadbury, 
Rowntree, Lyons, Courtaulds. However in small firms and other industry settings such as office work, administration, construction, transport and communications, mining, shipbuilding, and agriculture, systematic work study and sophisticated management structures were rare. The diffusion of Taylorism in Britain was therefore highly uneven and contrasts with the American experience of a more widespread shopfloor transformation. In Australia, the diffusion of scientific management was even more gradual than in Britain. One of the earliest examples of scientific management practice in Australian industry was the Melbourne clothing manufacturer, Pearson, Law \& Co. The managing director of the company, James Law, had read Taylor's Shop Management and applied the techniques of time study, systematic production planning and costing to the manufacture of collars, shirts and pyjamas. Other early examples included the NSW Railways, the car companies, and the McKay Harvester works, the country's largest manufacturer of agricultural machinery. During the 1930s, a local office of the Bedaux consultancy was also established and worked for a dozen of the country's leading manufacturers. However, prior to World War II, such examples of formalised control over work were rare. In contrast to the new mass production sectors, the vast majority of Australian manufacturing remained primitive and unsophisticated. In the metal industries of the 1920 s, despite the restructuring of the metal trades awards to encourage greater use of mass production and payment by results, the take-up of quantity production methods was limited. This reflected the impact of the Depression, the lack of applicability of such techniques amongst small and medium size enterprises, and union resistance to attempts to dilute and deskill the work process. Indeed, it was not until after World War II that scientific management attained more widespread use in Australia. Like Britain, the war resulted in a dramatic modernisation of industry, including the broader adoption of mass production, the spread of formal production planning, and further growth of payment by results. In Australia, management consultants and multinational companies were particularly important in the diffusion of scientific management during the 1940s and 1950s. Here both British and American influences were important. For instance many of the early consultants were English, and British multinationals, such as the chemical company ICI, imported scientific management practice from their UK parent operations. During the post-war decades, Australian industry also became increasingly receptive to American management practice. This was evident in post-war management publications which highlighted the role of American multinationals and promoted visiting American management experts. However, as was the case in Britain, survey evidence suggests such sophisticated systems of shopfloor control remained the preserve of larger foreign-owned enterprises and work relations in smaller firms remained informal.

\section{Managing Employment : from Paternalism to Personnel Management}

Just as the organisation of work changed significantly in British and Australian industry during the first half of the twentieth century, so too patterns of employment were also reshaped by employers in order to attain greater control over their workforce. However, like the example of scientific management, the adoption of more formalised systems of personnel management was a slow and drawn out process in both economies, with significant variation between firms reflecting differences in size, industry and the values of senior managers. As has been noted, in small firms in Britain and Australia the management of the workforce was based on simple, personal 
supervision and employment practices were often basic. For Australian employers, prior to World War II there appeared little need to formalise employment or training practices. High levels of unemployment during the inter-war years ensured a constant supply of labour and the threat of dismissal remained a powerful motivator of employee performance. Some larger firms did develop more systematic employment practices and formal sets of rules governing employee behaviour. One of the most advanced was the NSW Railways which by 1913 was Australia's largest employer and developed a highly bureaucratic labour policy including career paths, promotion through a hierarchy of grades, an appeals system, fixed pay increments and pension rights. Large retail stores provided another example of formalised employment relations, which by the early 1900s included formal selection procedures and rule books aimed at improving customer service and sales. The development of welfare programs also demonstrated a more formal and co-ordinated approach to workforce management. Welfarism sought to gain the loyalty of the workforce through demonstrations of employer benevolence, in much the same way that the entrepreneur emphasised his paternal role over the small firm. Examples included the provision of superior amenities, encouragement of social and recreational activities, profit-sharing schemes, sickness and accident benefits, or company provided services and housing. Employers emphasised that welfarism, far from being a philanthropic gesture, made good business sense. A contented and healthy workforce, it was argued, was also a more productive one. Welfare programs could also be used to disseminate managerial values and promote a unitarist workplace culture. In comparative perspective, the nature and extent of welfarism appears to have been more extensive in Britain than Australia. British nineteenth century traditions of paternalism provided a model for the later development of more formal welfare schemes during the 1920s. Indeed, despite the decline in paternalist practices in Britain during the early 1900s, paternalism survived as an important labour control strategy within major companies such as Lever, Cadbury, and Rowntree as well as sectors such as potteries, wool and worsted, brewing and footwear. Following World War I, company welfarism expanded significantly in British industry, especially in the newer industries. Company pension provision grew markedly in the 1920s. The railway companies and the gas industry continued to favour an explicitly welfarist approach and their monopoly position facilitated the financing of sophisticated welfare schemes. Company-based welfarism was also evident in metal manufacture, glass (Pilkingtons), shipbuilding, tobacco, electrical engineering, paper and cotton manufacture. In some cases, institutionalised benefits and company sports and welfare amenities helped to take the edge off impersonal corporate management and the stultifying effects of work reorganisation and deskilling. The Singer Corporation, for example, introduced a range of welfarist schemes, including sports facilities and a social club, in the decade after the 1911 strike in an attempt to divert workers from the attractions of industrial unionism. Similarly, ICI sweetened the pill of scientific management by an extensive programme of welfare benefits between the wars. The quiescent industrial relations records of both plants between 1920 and 1950 testify to the success of such schemes in assuaging industrial conflict. Some of the traditional stalwarts of personalised paternalism, including the Quaker employers Rowntree and Cadbury, moved in the opposite direction, bolting on a more explicit commitment to scientific, or 'systematic' management (shorn of its Taylorite hostility to trade unions) to their existing welfarist work regimes. As Rowlinson has noted, these managerial initiatives tended to be overlooked because they were introduced in a consensual rather than a confrontational fashion. This was indicative of a growing convergence between the 'human factor' 
management theorists and the Taylorists which congealed into personnel management and the 'work study' movement of post-1945. By 1939 there were about 1,800 welfare officers employed in British industry, something of an indication of the propensity of British capital to balance the use of both the carrot and the stick in their approaches to the management of labour. However, it remained largely the big corporations in the new, more buoyant industries and/or in monopoly market positions that had the resources and more sophisticated managerial structures, as well as the profit margins, to sustain a deep commitment to systematic welfarist strategies. In Australia, interwar examples of welfarism were evident amongst some larger employers in the manufacturing, retail and mining industries. Importantly the example of British welfare practice was an important influence. In some cases the influence was direct through the importation of parent company practice by local subsidiaries of British firms. Examples included local subsidiaries of British companies such as the tobacco firm W.D. \& H.O. Wills, British Tube Mills, Bryant \& May, ICI and Dunlop Rubber. ${ }^{3}$ In other cases, local firms mimicked British welfare practice. For instance the Australian textile firm of Geo. A. Bond \& Co. during the 1930s provided a wide range of facilities for its female workforce modelled on the practice of British textile companies. This included swimming and tennis clubs, physical culture classes held in a gymnasium, dances arranged by a social club, and a lending library. As management stated in publicity for their schemes, the cost of considering the 'human element' was more than compensated by the 'presence of a happy enthusiasm with which the employees apply themselves to their tasks'. Another example of advanced welfarism occurred within the Collins House group of companies, whose executives were deeply affected by the example of British corporate welfarism. However, such formalised welfare programs were exceptions to a general rule of employment informality in Australia prior to the 1940s. For instance a survey by Mauldon in 1931 found only 76 companies with welfare programs, including 17 in the clothing industry and 11 in retailing. Indeed, in contrast to the 1800 welfare officers in British industry in 1939, welfare officers in Australian factories were a rare occurrence in the inter-war years and it was not until World War II that they appeared in Australian factories in any significant number. Here the initiative was driven by the government which undertook the training and advocacy for formalised welfare and personnel management in the melee of wartime munitions production. Underlining the similarities of British and Australian employer practice, in the training of these pioneer personnel managers the Australian government looked to the example of British industry, particularly research around fatigue and working hours, improved amenities and ways of reducing labour turnover and absenteeism. This government-initiated focus on personnel management bore fruit after the war, as employers grappled with a full employment economy and pent-up consumer demand. During the later 1940s there was a dramatic increase in the number of personnel managers engaged in Australian industry, with labour scarcity proving a powerful incentive for the more widespread adoption of more formalised recruitment, induction, training and communications practices.

\section{Industrial Relations and Collective Bargaining}

Parallel with the evolution of sophisticated labour management structures and welfarism, Australian and British employers also developed more formalised approaches to the management of industrial relations during the first half of the twentieth century. In both countries the growing collective organisation of workers in 
trade unions during the nineteenth and early twentieth centuries challenged the unilateral power of employers, as workers bargained collectively over wages and working conditions. Employer responses to this challenge in both countries once again highlight significant similarities, although establishment of a system compulsory state industrial arbitration in Australia did differ from the British experience. In Britain, trade union organisation dated from the late eighteenth century, though relatively few workers outside the skilled craft artisans managed to sustain permanent organisations before the 1880s. The exceptions were the cotton factory workers and the coal miners. The key period for trade union expansion in both countries were the years from the 1880s to 1920 when new mass unions of unskilled workers spread across industries such as mining, shearing, the railways, maritime and road transport, boot-making, construction, clothing, as well as retail and clerical work. By 1920, union membership covered about 45 per cent of the British workforce ( 8.3 million employees), and 52 per cent of the Australian workforce (703,000 employees). One response to increasing union organisation was greater employer coordination. In Britain by 1914, a formidable matrix of industry-wide federations and local employers' associations existed. The main goal of employer organisations was to protect managerial prerogatives against the 'encroachments' of trade unions. In the 1880 s and 1890s, a plethora of coercive strikebreaking weapons enabled employers' associations to root out workers' organisations, or at least limit their influence.

However, the power and influence of employer organisations varied. They were relatively strong in coal, cotton, engineering, shipbuilding, printing and construction, and weak in iron and steel, transport, distribution, quarrying, chemicals and clothing. This mirrored the patchy coverage of trade unions. Whilst employers' organisations were strong at the local level, their powers were undermined by regional and sectional splits, whilst national collective bargaining was still relatively weak pre-1914. The majority of employers remained non-members prior to World War I and companylevel managerial policies and internal authority structures thus remained of paramount importance. In Australia, while early nineteenth century employer organisations tended to be transitory and impermanent, by the 1880s, employers had also begun to organise on a more permanent basis. For example, a major union victory in the bootmaking industry in 1884 provided the impetus for the formation of the Victorian Employers Union as well as a variety of industry and trade associations. Tight labour conditions and further union victories strengthened the trend towards greater combination as employers sought to conciliate with unions over wages and working conditions. The advantages of employer coordination were ably demonstrated in Australia during the 1890s Depression. In particular, the Maritime Strike of 1890 and related disputes in shearing and mining provided employers with an opportunity to undermine trade unionism. Assisted by a deteriorating economic environment and the active support of colonial governments, a combination of shipping, pastoralist and coal mining employers were able to break the strikes and institute 'freedom of contract'. As the depression deepened, employers ignored union agreements, bargained with workers individually and instituted wage cuts and work intensification. While the pattern of employer opposition to trade unionism is similar in both Britain and Australia, one source of major difference was the establishment in Australia of a system of compulsory state industrial arbitration during the later 1890s and early 1900s. Under the compulsory arbitration systems finalised in New South Wales in 1901 and at the Commonwealth level in 1904, trade unions were granted legal standing and could bring employers before the tribunals to resolve employee grievances. The courts also had the power to make enforceable awards setting down 
minimum wages and working conditions. Employers vigorously opposed this state intervention arguing it would increase costs, and by encouraging unions, impede efficiency. However, despite the vehemence of employer opposition, arbitration offered Australian employers a number of advantages. First, while the setting of minimum wages and working conditions may have reduced employer flexibility over labour costs, for larger enterprises such reform also offered to alleviate competition from smaller, low-wage producers. Second, the linking of 'fair and reasonable' wages under arbitration to a system of tariff protection, held clear benefits for manufacturers. Third, arbitration tribunals provided a further source of labour discipline, which while independent of management, commonly viewed the interests of the nation and industry as one and the same. Finally, while the arbitration tribunals forced employers to recognise trade unions, they also assisted in the preservation of managerial prerogative by limiting the scope of collective bargaining to a narrow range of industrial issues. While the arbitration system provided a clear point of difference in the institutional context facing Australian and British employers, it would be a mistake to assume that this more explicit form of state regulation resulted in fundamental differences in the behaviour of Australian employers in comparison to their British counterparts. Many of the advantages to capital associated with compulsory arbitration outlined above also applied to formal industry-wide collective bargaining, sometimes aptly referred to as 'procedural control', which extended rapidly in Britain from c1890 to c1920. In both countries, employers up until World War II were engaged in a battle with unions to maximise their control over the workforce, minimise wages and increase work effort. Often this involved an explicit rejection of trade unionism in the workplace and the development of anti-union strategies. A good example of such a confrontational approach to industrial relations in the Australian case was the country's major steel producer BHP, which victimised union delegates, established a company union, used 'staff' employees to act as strikebreakers, and in the 1920s, used a lock-out and closure of its plant to win major reductions in wages and working conditions. Similar anti-union approaches were also evident in the coal-mining, timber and metal manufacturing industries. Rather than a constraint on employer activism, the arbitration system proved an important ally in the disciplining of militant unions, the promotion of payment by results and work reorganisation, and court sanctioned wage cuts in periods of recession. In Britain, despite gains by organised labour during World War I, the onset of economic recession from 1920 and the subsequent two decades of depression and mass unemployment provided the opportunity for employers to move on to the offensive. A multi-pronged 'counter-attack' ensued, with employers' organisations spearheading a campaign to cut labour costs, victimise labour activists, neutralise industrial conflict and reassert employers' unilateral control over production management. This was most evident in the older, most depressed staple sectors of the economy, including cotton textiles, heavy engineering, and coal mining, where the employers' organisations revived a series of coercive weapons to discipline the unions, including the victimisation of activists, labour replacement in strikes and the lock-out. Such actions underwrote and energised a resurgence of unilateral managerial control in the mills and the pits, which bolstered the capacity of individual employers to increase workloads and contributed to a collapse in union membership. In addition to victimisation, company unions and other modes of coercive control, some employers also emphasised welfarist and participatory practices in order to thwart workplace unionism. Paternalist-style employers argued that a more 'personal touch' guarded against industrial conflict. The introduction of social and sporting clubs, magazines 
and newsletters aimed at engendering a 'company spirit' amongst the workforce in preference to external affiliations. More directly, a worker's participation in profit sharing schemes and provident funds was commonly conditional upon the maintenance of industrial harmony. Some employers also sought to lessen industrial conflict through the introduction of joint consultative arrangements. A major initiative in the British context was the government introduction of Whitley Committees from 1917, which aimed to create collective bargaining mechanisms for many of the least organised industries which lacked voluntary provision. In Australia, major employers such as the NSW Railways imported 'Whitleyism' in 1919, establishing joint committees of management and employee representatives with the goals of increasing productivity and promoting workplace harmony. However, the power of organised capital did not go unchallenged. The capacity of workgroups and trade unions to resist may well have been undermined by economic recession and unemployment, but what is surprising is the extent to which struggle continued in some sectors, especially when traditional work customs were challenged. In Britain, despite unemployment rates in excess of 40 per cent, a series of strikes took place in the cotton textile industry throughout the early 1930s against work intensification. As Reid and Zeitlin have shown for shipbuilding and engineering, union branches and work groups were capable of retaining a considerable degree of control at the point of production, especially in the more buoyant newer sectors of light engineering (such as aircraft manufacture) developing between the wars. In Australia, there were also numerous examples of labour resistance and collective bargaining during the inter-war years. In strongly organised sections of the labour movement such as the metal trades, mining and shearing, workplace collective bargaining remained an enduring feature. In the metal industry, unions such as the engineers, boilermakers and sheet-metal workers bargained over overtime, work-practices and over-award payments. They also successfully resisted attempts by employers to dilute tradesmen's work and introduce payment by results. In public-sector enterprises such as the railways and shipbuilding, the strength of workplace trade unionism led to the formation of shop committees which bargained with management over a range of issues. During the later 1930s, economic recovery, declining unemployment and growing labour militancy resulted in a broadening of workplace resistance. In the clothing and footwear industries, female workers struck against attempts at work intensification, and in the steel industry the Communist-led Federated Ironworkers Association succeeded in raising levels of workplace unionism to near closed-shop levels.

World War II marked a watershed in the industrial relations approaches of both British and Australian employers. The wartime crisis, state intervention, the revival of trade union power and the return to full employment combined to shift the balance of workplace power from capital to labour. The challenge to managerial authority at work in the 1940s came from two sources: from the state as it took control of the war economy in the national interest; and from below, as workers' bargaining power, confidence and capabilities revived. In terms of the former, state intervention in wartime industry was important in the establishment of joint consultative mechanisms which recognised the voice of workers and their collective representatives. In Britain, the Essential Works Order and the creation of Joint Production Committees (JPCs) heralded a change in social relations on the shop floor whereby power was stripped from management and effective joint regulation of work established. By 1944 there were JPCs in 4,500 factories which regulated areas previously regarded as sacrosanct to management, such as staffing, production organisation, wage setting and bonuses, 
vetos over dilution, and issues of discipline. Such joint regulation of the workplace also assisted the growth of shopfloor union representation and revived concepts of workers' control. A similar process occurred in Australian wartime industry, with a federal Labor Government following the British example, and in 1942 mandating joint production advisory committees in all government-controlled factories. Such wartime examples of joint consultation were expanded in the post-war period in a number of private-sector employers as part of a more consultative industrial relations approach. During the post-war years, the changed economic environment and labour's increased bargaining power limited the efficacy of confrontational industrial relations as a general strategy. Booming product demand added to employer desires to avoid industrial disputation which might upset production. Further, many employers now viewed trade unionism as an inevitable feature of the industrial landscape. A common response in both Britain and Australia, was for employers to seek to codify the employment relationship in order to maintain stable workplace relations; what has been termed a 'constitutional' approach to industrial relations. In Australia, this resulted in employers retreating behind the provisions of the relevant industrial awards, interpreting their obligations in a narrow, legalistic fashion, and seeking to defend their prerogatives from union claims. Such an approach was pronounced amongst the major employer associations, which adopted a conservative approach to union negotiation and sought to 'hold the line' against union wage claims. Inevitably however, labour shortages also led to competitive bidding by employers and the growth of over-award payments challenged employer unity. Indeed in both Australia and Britain there were prominent examples of larger firms seeking to develop more sophisticated industrial relations strategies, which in some cases involved a more consultative approach to union relations and attempts at productivity bargaining.

\section{Conclusion}

Our aim in this paper has been to compare the history of employer practice in British and Australian industry during the first half of the twentieth century. As we noted at the outset, Australia's system of industrial relations, based upon compulsory industrial arbitration, has often been seen as distinctive in comparison to other countries such as Britain, which has been characterised as a more 'voluntarist' system, based on less state intervention and greater direct interaction between employers, workers and their unions. However as our analysis demonstrates, rather than major differences what is notable in comparing British and Australian employer practice are the fundamental similarities. At the level of work relations, while Australian manufacturing lacked the pervasive nineteenth century British tradition of internal sub-contracting and was slower to adopt scientific management and mass production techniques, these differences related more to the later development of manufacturing industry in the Australian setting and its far smaller scale. Indeed, the majority of Australian and British industrialists during the inter-war years shared a reliance upon the informal personal control of the foreman and a reticence to embrace more formalised techniques of scientific management and production control. Moreover, following World War II, Australian manufacturers appeared to catch up quickly in adopting scientific management, as manufacturing industry modernised and expanded. In terms of employment relations, a similar pattern of employer practice emerged in both countries. Again, informal employment practices prevailed in the majority of workplaces, however in larger, more innovative firms, more formalised practice emerged, highlighted by the introduction of employee welfare programs. Once again 
the extent and nature of welfarism was more limited in the Australian context, although by the end of the 1940s, Australian employers had increasingly embraced the broader concept of personnel management in response to state advocacy, a full employment economy and growing consumer demand.

Finally, in terms of industrial relations, clearly arbitration did present Australian employers with a different regulatory context from that of their British counterparts. Arbitration encouraged higher levels of union density and institutionalised bargaining structures through a complex pattern of industry and occupational awards. However again there were also remarkable similarities in employer practice despite different regulatory regimes. Prior to World War II, large segments of British and Australian employers responded to trade unionism in a largely confrontational and combative manner. At the workplace level, this involved the victimisation of unionists and strike-breaking. In some cases, more advanced firms in both countries also used their welfare programs as a means to undermine unionism. Greater employer unity was also a central strategy in both countries and spurred the establishment of employer associations and efforts at greater employer coordination and multi-employer bargaining. In the wartime and post-war environment of labour scarcity and increased worker bargaining power, employers in both countries were forced to re-evaluate their traditional opposition to unions, and shifted to a more defensive constitutional approach. Moreover, it is often overlooked that state arbitration also grew in importance in Britain following the passage of the Conciliation Act in 1896 and for more than a decade, 1940-51, arbitration remained compulsory under wartime Order 1305. What then explains the similarities in Australian and British employer practice? While we have not sought to determine this directly in this article, we believe a key factor worthy of further investigation was the close economic and social connections that existed between managers in both countries, reflecting the broader inter-linkages of the British and Australian economies. As Cochrane has highlighted, Australian economic development occurred within the broader context of its role as a dominion within the British Empire and Australian industrialisation prior to World War II was heavily reliant upon British investment and technical know-how. British-owned companies dominated in many areas of Australian industry including mining, steel, chemicals, paper, rubber and metal manufacturing and British capital underpinned the countries two biggest corporate entities, the Collins House group and BHP. Moreover, prominent Australian industrialists were also strongly linked to the heart of British capital and finance. In this respect, the mimicking of British management practice can be explained through the significant role of British companies and financial interests within the fledgling Australian manufacturing sector. Such similarities in employer practice then represent a sub-set of the 'strong ties' implicit within the Commonwealth as an economic network. As Robertson and Singleton argue:

In the case of the Commonwealth, high degrees of shared language, history, customs and legal systems, as well as common educational systems for the elite, acted together to bond nations that were geographically ... disparate.

Following World War II, the Anglocentric nature of Australian management began to break down through a growing adoption of American production and management practice. This trend as we've seen was predated by examples such as BHP in steel, and General Motors and Ford in automotive manufacture, however after the war the entry of American multinationals and the importation of American consulting expertise provided alternative management models. During the 1950s and 
1960s, employer practice in Australia developed a more distinctive appearance, as manufacturing industry broadened and modernised, and an increasingly multicultural workforce developed through extensive post-war European migration. Again, these micro trends reflected changes in the broader economic relationship between Britain and Australia, and the growing economic dominance of American capital.

While comparative industrial relations has tended to contrast the British and Australian experience, our review of the history of employer practice suggests that during the first half of the twentieth century, Australian employers closely followed the example of British management practice, and there was in fact a great deal of similarity in the actions of employers in both countries. Overall, our analysis highlights how comparative study can reveal not only points of difference, but also underlying similarities. An implication for future research, is the importance of linkages between national business communities and how such connections affect the global diffusion of management practice.

\section{References}

Daniel Nelson, Managers and Workers: Origins of the New Factory System in the US, 1880-1920, University of Wisconsin Press, Madison WI, 1975;

Sanford Jacoby, Employing Bureaucracy: Managers, Unions and the Transformation of Work in American Industry, 1900-1945, Colombia University Press, New York, 1985 ;

Howard Gospel, Markets, Firms and the Management of Labour in Modern Britain, Cambridge University Press, Cambridge, 1992;

Christopher Wright, The Management of Labour: a History of Australian Employers, Oxford University Press, Melbourne, 1995;

Arthur McIvor, A History of Work in Britain, 1880-1950, Palgrave, Houndmills, 2001. 2.

Craig Littler, The Development of the Labour Process in Capitalist Societies, Heinemann, London, 1982;

Steven Tolliday and Jonathan Zeitlin (eds), The Power to Manage? Employers and Industrial Relations in Comparative-Historical Perspective, Routledge, London, 1991.

Other examples include Jacques Ferland and Christopher Wright, 'Rural and Urban Labour Processes: a Comparative Analysis of Australian and Canadian Development', Labour/Le Travail, vol. 38, 1996, pp. 142-169;

Howard Gospel and Andrew Pendleton, 'Finance, Corporate Governance and the Management of Labour: a Conceptual and Comparative Analysis', British Journal of Industrial Relations, vol. 41, no. 3, 2003, pp. 557-582;

Marie-Geneviève Dezès, Kenneth Lunn, Arthur McIvor and Klaus Tenfelde, 'Employers and Trade Unions in the late Nineteenth Century in Britain, France and Germany', in Jean-Louis Robert, Antoine Prost and Chris Wrigley (eds), The Emergence of European Trade Unionism, Ashgate, Aldershot, 2004, pp. 204-214. 3.

Greg Bamber and Ed Snape, 'British Industrial Relations', in Greg Bamber and Russell Lansbury (eds), International and Comparative Industrial Relations, Allen \& Unwin, Sydney, 1987, p. 43; 
P.K. Edwards, Conflict at Work: a Materialist Analysis of Workplace Relations, Basil Blackwell, Oxford, 1986, pp. 168-184. 4. See for example William Howard, 'Australian Trade Unions in the Context of Union Theory', Journal of Industrial Relations, vol. 19, no. 3, 1977, pp. 255-273;

Braham Dabscheck, 'The Australian System of Industrial Relations: an Analytical Model', Journal of Industrial Relations, vol. 22, no. 2, 1980, pp. 196-219;

David Plowman, 'Industrial Relations and the Legacy of New Protection', Journal of Industrial Relations, vol. 34, no. 1, 1992, pp. 48-64. 5.

David Collier, 'The Comparative Method: Two Decades of Change', in Dankwart A. Rustow and Kenneth Paul Erickson (eds), Comparative Political Dynamics: Global Research Perspectives, HarperCollins, New York, pp. 7-31. 6.

Peter Cochrane, Industrialization and Dependence: Australia's Road to Economic Development, 1870-1939, University of Queensland Press, St.Lucia, 1980. 7. Gospel, Markets, Firms, p. 3. 8. Witness the largely negative response to Taylorism in engineering trade journals such as Engineering and The Engineer. See for example The Engineer, 19 May 1911, p. 520;

McIvor, History of Work, pp. 68-70, 85-93; Littler, Development of the Labour Process, pp. 94-96. 9.

Cochrane, Industrialization and Dependence, pp. 31-44. 10.Ibid., p. 43. 11.Ibid., pp. 2, 10-11;

Greg Patmore, Australian Labour History, Longman Cheshire, Melbourne, 1991, pp. 142, 146. 12.

F. Mauldon, Mechanisation in Australian Industries, University of Tasmania, Hobart, 1938, pp. 41-44; Colin Forster, Industrial Development in Australia, 1920-1930, Australian National University, Canberra, 1964, pp. 37-57, 118-122;

Grant Fleming, David Merrett and Simon Ville, The Big End of Town: Big Business and Corporate Leadership in Twentieth-Century Australia, Cambridge University Press, Cambridge, 2004, pp. 16-19, 206-207. 13.

Richard Edwards, Contested Terrain: the Transformation of the Workplace in the Twentieth Century, Basic Books, New York, 1979. For Australian examples see Anon., 'Courtney \& Bohlsen's', Australasian Manufacturer, 24 June 1922, pp. 14-16; Anon., 'The Man Behind the Factory', Australasian Manufacturer, 2 June 1934, p. 25 and 15 December 1934, p. 25. 14. Littler, Development of the Labour Process, pp. 77-79. 15.

Joseph Melling, '"Non-Commissioned Officers": British Employers and their Supervisory Workers, 1880-1920', Social History, no. 5, 1980, pp. 183-221. For an Australian example see Anon., 'Australian Can-Making Machinery', Australasian Manufacturer, 14 July 1917, p. 16. 16. 
Raelene Frances, The Politics of Work: Gender and Labour in Victoria, 1880-1930, Cambridge University Press, Melbourne, 1993, pp. 44, 47;

Jim Hagan and Chris Fisher, 'Piece Work and Some of its Consequences in the Printing and Coal Mining Industries in Australia, 1850-1930', Labour History, no. 25, 1973, pp. 19-39;

Kosmas Tsokhas, 'The Shearing Labour Process, 1900-1914', Labour History, no. 59, 1990, pp. 87-103. 17. Jacoby, Employing Bureaucracy, p. 43;

Anon., 'Steelworker 1928', BHP Journal, no. 2, 1978, pp. 54-55;

Peter Cochrane, 'Anatomy of a Steel Works: the Australian Iron and Steel Company Port Kembla, 1935-1939', Labour History, no. 57, 1989, pp. 68-69. 18.

Alfred Williams, Life in a Railway Factory, M. Kelley, New York, 1969, pp. 302306. 19.

Christopher Wright, 'The Formative Years of Management Control at the Newcastle Steelworks, 1913-1924', Labour History, no. 55, 1988, pp. 55-70;

Greg Patmore, '"American Hustling Methods": the Lithgow Small Arms Factory 1912-1922', Labour History, no. 67, 1994, pp. 42-56;

J. Sutterby, Workers and the Rise of Mass Production: Holden's in the 1920s and 1930s, BA Honours thesis, School of Social Sciences, Flinders University, 1981; Forster, Industrial Development, pp. 107-122;

Anon., 'Mass Production in Australia', Australasian Manufacturer, 13 December 1930, pp. 18-19, 38. 20.

Frederick W. Taylor, Scientific Management, Harper and Row, New York, 1964, p. 131. 21.

Kevin Whitston, 'The Reception of Scientific Management by British Engineers, 1890-1914', Business History Review, vol. 71, no. 1, 1997, pp. 228-229. 22.

Kevin Whitston, 'Scientific Management and Production Management Practice in Britain Between the Wars', Historical Studies in Industrial Relations, no. 1, 1996, p. 51. 23.

Littler, Development of the La bour Process, pp. 94-95; Glasgow Labour History Workshop, 'A Clash of Work Regimes: Americanisation and the Strike at the Singer Sewing Machine Company, 1911', in William Kenefick and Arthur McIvor (eds), Roots of Red Clydeside, 1910-1914?, John Donald, Edinburgh, 1996, pp. 193-213. 24.

Littler, Development of the Labour Process, pp. 99-145; Whitston, 'Scientific Management', p. 48; Lyndall Urwick and Edward Brech, The Making of Scientific Management, Pitman, London, 1947; Gospel, Markets, Firms, pp. 54-55; 
Robert Fitzgerald, British Labour Management and Industrial Welfare, 1846-1939, Croom Helm, London, 1988; Matthias Kipping, 'Consultancies, Institutions and the Diffusion of Taylorism in Britain, Germany and France, 1920s to 1950s', Business History, vol. 39, no. 4, 1997, pp. 67-83. 25. See Roger Penn, 'Skilled Manual Workers in the Labour Process, 1856-1964', in Stephen Wood (ed.), The Degradation of Work, Hutchinson, London, 1982, pp. 90-108; Richard Whipp, Patterns of Labour: Work and Social Change in the Pottery Industry, Routledge, London, 1990, pp. 195212;

Arthur McIvor, Organised Capital: Employers' Associations and Industrial Relations in Northern England, 1880-1939, Cambridge University Press, Cambridge, 1996, pp. 207-209, 265-268. 26.

Frances, The Politics of Work, pp. 84-87;

Greg Patmore, 'Systematic Management and Bureaucracy: the NSW Railways Prior to 1932', Labour \& Industry, vol. 1, no. 2, 1988, pp. 311-315;

Lucy Taksa, 'Scientific Management and the General Strike of 1917: Workplace Restructuring in the New South Wales Railways and Tramways Department', Historical Studies in Industrial Relations, no. 4, 1997, pp. 37-64;

Wright, Management of Labour, pp. 26-28; John Shields, Skill Reclaimed: Craft Work, Craft Unions and the Survival of Apprenticeship in New South Wales, 18601914, PhD thesis, Department of Economic History, University of Sydney, 1990;

Sandra Cockfield, The Interaction of Industrial Tribunals and Workplace Industrial Relations in Australia: the Metal Trades, 1900 to 1929, PhD Thesis, Faculty of Commerce and Management, Griffith University, 1998. 27. Wright, Management of Labour, pp. 66-72;

Christopher Wright, 'The Development of Incentive Payment Systems in Australian Manufacturing Industry, 1945-1970', Labour \& Industry, vol. 4, no. 1, 1991, pp. 95118. 28.

Christopher Wright, 'From Shopfloor to Boardroom: the Historical Evolution of Australian Management Consulting, 1940s to 1980s', Business History, vol. 42, no. 1, 2000, pp. 86-106;

Work Study in ICIANZ, series N21/751, Australian National University Archives; Work Study Appreciation Course - Botany Factory, Personnel Group Records, ICI Australia;

Christopher Wright, 'Taylorism Reconsidered: the Impact of Scientific Management Within the Australian Workplace', Labour History, no. 64, 1993, pp. 34-53. 29.

Greg Patmore, 'Arbitration and Bureaucracy: the New South Wales Railway Commissioners, 1892-1914', Journal of Industrial Relations, vol. 30, no. 4, 1988, pp. 567-570; 
Greg Patmore, 'Labour History and Labour Process: the New South Wales Railways Before 1878', Australian Historical Studies, vol. 23, no. 93, 1989, pp. 426-441;

Gail Reekie, "'Humanising Industry": Paternalism, Welfarism and Labour Control in Sydney's Big Stores 1890-1930', Labour History, no. 53, 1985, pp. 1-19;

Bradley Pragnell, 'Selling Consent': A History of Paternalism and Welfarism at David Jones Limited, 1838-1958, PhD Thesis, School of Industrial Relations \& Organisational Behaviour, University of New South Wales, 2001. 30.

Sanford Jacoby, Modern Manors: Welfare Capitalism Since the New Deal, Princeton University Press, Princeton, NJ, 1997;

Fitzgerald, British Labour Management; Advisory Council of Science and Industry, Industrial Co-operation in Australia, Executive Committee of the Advisory Council, Melbourne, 1920. 31.

Fitzgerald, British Labour Management, pp. 10-11. For an argument that the emergence of corporate capitalism saw the decline of company welfarism, see Michael Marinetto, 'The Historical Development of Business Philanthropy: Social Responsibility in the New Corporate Economy', Business History, vol. 41, no. 4, 1999, pp. 1-20. 32.

Robert Fitzgerald, Rowntree and the Marketing Revolution, 1862-1969, Cambridge University Press, Cambridge, 1995, pp. 217-276;

Michael Rowlinson, 'The Early Application of Scientific Management by Cadbury', Business History, vol. 30, no. 4, 1988, pp. 373-395. 33. Rowlinson, 'The Early Application', p. 392. See also Michael Rowlinson, 'Quaker Employers', Historical Studies in Industrial Relations, no. 6, 1998, pp. 163-198. 34. Howard Gospel, 'Employers and Managers', in Chris Wrigley (ed.), A History of British Industrial Relations, Vol. 2, 1914-1939, Harvester, Brighton, pp. 179-180;

Fitzgerald, British Labour Management, pp. 184-185; S. Jones, 'Cotton Employers and Industrial Welfare Between the Wars', in J.A. Jowitt and Arthur McIvor (eds), Employers and Labour in the English Textile Industries, 1850-1939, Routledge, London, 1988, pp. 64-83. 35.

Nicola Balnave, Industrial Welfarism in Australia, 1890-1965, PhD thesis, Work and Organisation Studies, University of Sydney, 2002;

Anon., 'Manufacturing Tobacco, Cigars \& Cigarettes at Raleigh Park', Australasian Manufacturer, 3 December 1921, pp. 22-25;

Anon., 'Making Things in a Big Way', Australasian Manufacturer, 20 April 1935, pp. 158,168 ;

William Reader, Imperial Chemical Industries: a History, Oxford University Press, London, 1975, pp. 57-70; 
Personnel Group Records, ICI Australia; C. Smith, 'Production and Leisure', Manufacturing \& Management, September 1946, pp. 103-106. 36.

Anon., 'Fascinating Methods in Manufacture of Hosiery', Australasian Manufacturer, 4 June 1927, pp. 16-18. 37. Eric Ekland, 'Managers, Workers and Industrial Welfare: Management Strategies at ER\&S and the Sulphide Corporation, 1895-1929'. Australian Economic History Review, vol. 37, no. 2, 1997, pp. 137-157;

Eric Ekland, '"Intelligently Directed Welfare Work"?: Labour Management Strategies in Local Context: Port Pirie, 1915-29', Labour History, no. 76, 1999, pp. 125-148. 38.

F. Mauldon, 'Cooperation and Welfare in Industry', in D. Copland, (ed.), An Economic Survey of Australia, Annals of the American Academy of Political and Social Science, 1931, pp. 184-187. 39.

Wright, Management of Labour, pp. 44-46; Outline of the Industrial Welfare and Personnel Officers Training Course, series SP113/1, items 652/5/1, 662/5/- and 650/3/1, Australian Archives (hereafter AA);

Department of Labour and National Service (hereafter DLNS), How to Reduce Absenteeism and Increase Production, Commonwealth of Australia, Canberra, 1943; DLNS, Amenities in Wartime Factories, Commonwealth of Australia, Canberra, 1945;

DLNS, Planning Hours of Work, Commonwealth of Australia, Canberra, 1945. 40.

Wright, Management of Labour, pp. 44-65. 41.

Neville Kirk, Change, Continuity and Class: Labour in British Society, 1850-1920, Manchester University Press, Manchester, 1998, pp. 49-52;

McIvor, History of Work, pp. 200-207; Patmore, Australian Labour History, pp. 5861 ;

Malcolm Waters, Strikes in Australia: a Sociological Analysis of Industrial Conflict, George Allen \& Unwin, Sydney, 1982, pp. 82, 98-101; Stephen Deery and David Plowman, Australian Industrial Relations, McGraw-Hill, Sydney, 1983, p. 226. 42.

W. Garside and Howard Gospel, 'Employers and Managers', in Chris Wrigley (ed.), A History of British Industrial Relations, 1875-1914, Harvester, Brighton, 1982, pp. 57117 ;

Gospel, Markets, Firms, pp. 59-91; McIvor, Organised Capital, pp. 59-91. For the most comprehensive local study see Ronald Johnston, Clydeside Capital, 1870-1920: a Social History of Employers, Tuckwell Press, East Linton, Scotland, 2000, pp. 1242. 43. 
Arthur McIvor, 'Employers Organisations and Strikebreaking in Britain, 1880-1914', International Review of Social History, no.29, 1984, pp. 1-33. 44.

Garside and Gospel, 'Employers and Managers'. 45. T. Parsons, 'An Outline of Employer Organisation in the Victorian Manufacturing Industries 1879-1890', Journal of Industrial Relations, vol. 14, no. 1, 1972, pp. 23-28;

Alice Coolican, 'Solidarity and Sectionalism in the Sydney Building Trades: the Role of the Building Trades Council 1886-1895', Labour History, no. 54, 1978, pp. 18-19;

Frances, Politics of Work, pp. 46-49. 46. Waters, Strikes, pp. 102-106; Noel Butlin, 'Collective Bargaining in the Sydney Printing Industry, 1880-1900', Economic Record, no. 23, 1947, pp. 211-212;

Frances, Politics of Work, pp. 49-51, 69-71. 47. Patmore, Australian Labour History, pp. 102-120. 48. David Plowman, Holding the Line: Compulsory Arbitration and National Employer Co-ordination in Australia, Cambridge University Press, Melbourne, 1989, pp. 5-47;

David Plowman, 'Forced March: the Employers and Arbitration', in Stuart Macintyre and Richard Mitchell (eds), Foundations of Arbitration: the Origins and Effects of State Compulsory Arbitration, 1890-1914, Oxford University Press, Melbourne, 1989, pp. 135-155. 49.

Wright, 'The Formative Years'; Diane van den Broek, Industrial and Community Resistance: the Case of the 1929 Timber Strike, BA Honours Thesis, School of Industrial Relations \& Organisational Behaviour, University of New South Wales, 1993;

Tom Sheridan, Mindful Militants: the Amalgamated Engineering Union in Australia, 1920-1970, Cambridge University Press, Melbourne, 1975, pp. 101-108;

Sandra Cockfield, 'Arbitration, Mass Production and Workplace Relations: Metal Industry Developments in the 1920s', Journal of Industrial Relations, vol. 35, no. 1, 1993, pp. 28-33. 50.

McIvor, History of Work, pp. 183-210 51.

Jacqueline Rawson, 'Industrial Relations in the Australian Paper-Making Industry: a Brief Survey of the Expansion of the Paper-Makers' Union, 1900-1952', Journal of Industrial Relations, vol. 5, no. 1, 1963, pp. 38-45;

Tim Flay, Reflections on Arbitration: the Federated Tobacco and Cigarette Workers' Union of Australia, BCom Honours thesis, Department of Industrial Relations, University of Sydney, 1978; Patmore, Australian Labour History, pp. 147, 150. 52.

Alastair Reid, 'Employers' Strategies and Craft Production: the British Shipbuilding Industry 1870-1950', in Tolliday and Zeitlin, Power to Manage?, pp. 35-51; 
Jonathan Zeitlin, 'The Internal Politics of Employer Organization', in Tolliday and Zeitlin, Power to Manage?, pp. 52-80. 53.

Tsokhas, 'The Shearing Labour Process', pp. 94-96; Kosmas Tsokhas, 'Work Practices, Technological Change and Sheet Metal Workers, 1929-1970', Prometheus, vol. 7, no. 2, 1989, pp. 225-238;

Sheridan, Mindful Militants, pp. 54, 103-105. 54.

Malcolm Rimmer, and Paul Sutcliffe, 'The Origins of Australian Workshop Organisation, 1918 to 1950', Journal of Industrial Relations, vol. 23, no. 2, 1981, pp. 227-230. 55.

Frances, Politics of Work, pp. 144-145, 147, 164;

Cochrane, 'Anatomy of a Steelworks', pp. 73-77. 56. James Hinton, Shop Floor Citizens: Engineering Democracy in 1940s Britain, Elgar, Aldershot, 1994. 57.

Alan Ife, 'Employer/Employee Committees', in Institute of Industrial Management (ed.) Personnel Management Practices by Six Industrial Executives, IIM, Melbourne, 1946, p. 56;

Welfare and Production Committees at Salisbury, series SP113/1, item 660/2/-, AA;

Employee-Management Committees, series SP146, item 575/5/4, AA; Wright, Management of Labour, pp. 57-58. 58.

John Purcell and Keith Sisson, 'Strategies and Practice in the Management of Industrial Relations', in George Sayers Bain (ed.), Industrial Relations in Britain, Blackwell, Oxford, 1983, p. 115. 59.

Wright, Management of Labour, pp. 92-114;

McIvor, History of Work, pp. 227-231. 60.

R. Davidson, 'Government Administration', in Wrigley (ed.), History of British Industrial Relations, pp. 135-158;

Chris Wrigley, 'The Government and Industrial Relations', in Wrigley (ed.), History of British Industrial Relations, pp. 158-188;

Chris Wrigley, British Trade Unions Since 1933, Cambridge University Press, Cambridge, 2002, p. 14;

I.G. Sharp, Industrial Conciliation and Arbitration in Great Britain, Allen and Unwin, London, 1950. 61.

Cochrane, Industrialization and Dependence, pp. 31-50, 76-8. 62. Paul L. Robertson and John Singleton, 'The Commonwealth as an Economic Network', Australian Economic History Review, vol. 41, no. 3, 2001, p. 251. 63. 
Wright, Management of Labour, pp. 68-76; Ernst Boehm, Twentieth Century Economic Development in Australia, Longman, Melbourne, 1971, pp. 139-144;

Jock Collins, 'The Political Economy of Post-War Immigration', in Edward Wheelwright and Ken Buckley (eds), Essays in the Political Economy of Australian Capitalism, Australia and New Zealand Book Co, Sydney, 1978, pp. 105-129. 